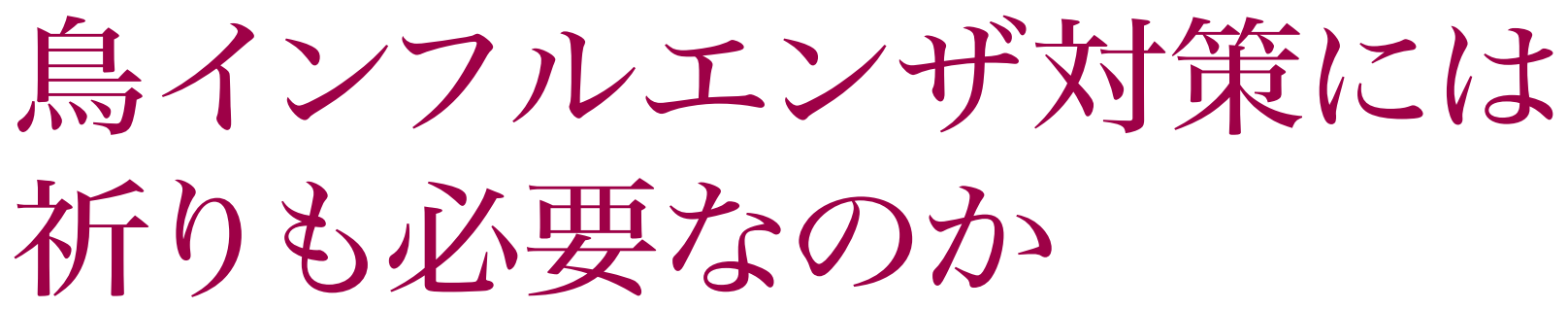

\title{
On a wing and a prayer
}

\section{Nature Vol.435(385-386)/26 May 2005}

Nature 2005 年 5 月 26 日号の鳥インフルエンザ特集では、人が大量感染して、 世界的に大流行する恐れのある鳥インフルエンザへの各国の対応の進展、そこ にみられる一貫性の欠如が浮き彫りにされている。しかし、これは大きな脅威 であり、いくつかの重点的に推進すべき対策があることは十分に明らかである。

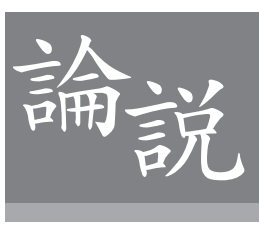

高度先進国では、数か月で数百万人が死ぬ。全世界の死 者数は数千万人。世界経済はズ夕ズ夕。これは、ハリウッ ド製空想映画ではない。現実化の可能性を帯びるように なったシナリオである。第一幕では、人が鳥インフルエン ザに感染し、非常に高い確率で人から人へ感染が広がる。 これが、既にアジア各地で始まっているのである。今、国 際社会が鳥インフルエンザ大流行の脅威を鎮めるための断 固とした行動に出ないかぎり、私たちは数年以内に抢そら く手痛い代償を払うことになるだろう。その時には、なぜ 準備を怠ったのか、という厳しい追及が待っている。

一方で、この話に疑いをもつ人々もたくさん抢り、彼ら はインフルエンザの世界的流行なんて悪質なデマか、科学 者がでたらめを言っているにちがいないと信じている。サ ポートケア、薬剤とワクチンがあれば、少なくとも富裕国は、 インフルエンザウイルスに容易に立ち向かえるはずだ。そ れに今は 2005 年であり、インフルエンザが大流行して全 世界で最大 5000 万人 (推定) が命を落とした 1918 年で はない。たしかにインフルエンザに関する科学と医学は大 いに進歩したが、公衆衛生面で効果的な対応をとる能力 はそれから何十年間たっても、ほとんぞ進歩していない。 テレビとインターネットの影響力を考えると、パニックが起 こる可能性は、どちらかと言えば、昔よりも高まっている。

1918 年のインフルエンザ大流行では、インフルエンザ ウイルスの新種のサブタイプに免疫のある者がいなかっ た。疫学の数理によれば、世界的流行病は地下の断層に
たとえられる。断層がいつか必ず崩壊して地震を引き起こ すように、世界的流行病も必ず発生する。ただし、地震と ちがって、世界的流行病の発生には事前に危険信号がみ られる傾向がある。警告ランプが、今、アジアで赤く点灯 しているのだ。今度は「大流行」となるのかぞうかを断言 できる者はいない。それでも H5N1 鳥インフルエンザウイ ルスはアジアで広く流行しており、その近縁種のいくつか に人は免疫がない。今、世界に必要なのは、最悪の事態 を想定して防衛計画を立てることである。そのための準備 は、どれほど進んでいるのだろうか。

世界的に大流行するようなウイルス株が出現する可能性 の非常に高い「るつぼ」とも言うべきなのが家禽とブ夕だ。 これらの動物が感染している鳥インフルエンザウイルスを 絶滅させる役割を担っているのが、各国の農政・獣医行 政当局、国連食糧農業機関と世界動物衛生機関 (OIE) だ。 公衆衛生の側面は、各国の保健当局と世界保健機関 (WHO) が責任を負う。ところが、この点での国際的連携 は不安定で、確固たる目的や統一性がほとんぞ感じられな い。活動資金も大きく不足して抢り、各国の公衆衛生方針、 主権、そして貿易や経済的利害の対立によって、活動は いたるところで弱体化している。

もし、今から 5 年後にインフルエンザの大流行が起きる と仮定すると、製薬やワクチンのメーカーを奨励して、大 流行による被害を少なく抑えるだけの時間的余裕はあると 言える。しかし、そのためには緊急に行動をとる必要があ 
る。現状では、世界的流行をするインフルエンザウイルス に対するワクチンを製造するには、流行が始まってから少 なくとも 6 か月を要する。これでは遅すぎるのである。ワ クチンができあがる前に、大流行による最悪の結果を迎え てしまうのである。

現状よりも速くワクチンをつくるためには、戦略的軍事 兵器研究に匹敵するような研究活動が必要で、通常の努 力では足りない。また、量的にも流行時に急増する需要を 満たすのに十分な量のワクチンを作る必要がある。現在の 全世界のワクチン製造能力では、 4 億 5000 万人分のワク チンしか作れない。製造能力の増強をはかるには、既存の インフルエンザワクチンに対する平常時の需要を引き上げ る保健政策が必要である。抗ウイルス薬も同様だ。

しかし最悪のシナリオでは、インフルエンザの世界的流 行は 2 年以内に起こるといわれている。こうなると、ワク チンがないばかりか、薬も不足する。たよりは、関係国の 政府やWHO が、インフルエンザウイルスの出現時にウイ ルスを発生源で絶滅させることである。そのためには、動 物に感染したインフルエンザウイルスを絶滅させて、世界 的流行を防止することを最優先課題としなければならない のである。

\section{行動の時}

残念ながら現状では、各国政府や国際機関によって、こ の課題が解決される見込みは薄い。例元ば、世界的流行 をするウイルス株の出現を推測できるような鳥ウイルスや ヒトウイルスの遺伝子変異をほぼリアルタイムで監視する 研究を行うべきである。ところが、鳥インフルエンザが流 行している国で、適切かつ継続的な監視プログラムを構築 するための国際的な資金援助はない。海外の研究者がウイ ルス流行国からデー夕を入手したいと思っても、信頼感の 醸成とオープンな情報共有のために必要な協力活動に当事 国が本格的に参加していないため、それができない。また、 インフルエンザ大流行の最前線に置かれるアジア各国への 薬剤の提供などのインセンティブが国際社会から与えられ ていない。これに加えてアジア各国は、国内で収集した数

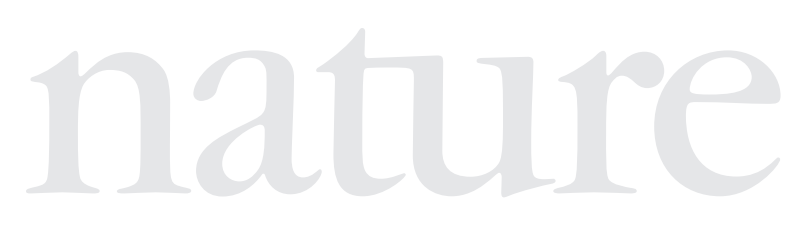

少ないデータを公表することを渋っている。データの解析 結果によっては、他国との貿易や国内経済に悪影響を及 ぼす恐れがあるからだ。監視制度がうまく働いていない現 状は、何ら意外なことではない。

アジアにおける鳥インフルエンザ感染者ひとりひとり は、世界にとって脅威となる可能性がある。世界のウイル ス学研究者は、現場に常駐する必要がある。患者を迅速 に診断し、患者と患者が接触したすべての人に抗ウイルス 薬を投与して治療することで、インフルエンザウイルスを 発生源で絶滅させることを目指す必要がある。またウイル スの遺伝的特質を解明して、それをウイルスの疫学的・病 理学的研究に結びつけるために、すべてのウイルス試料と デー夕を直ちに共有できるようにする必要がある。ところ が、そのいずれもが十分に行われていない。各国政府の 対応は身が入っておらず、中途半端で、あまりに遅い。ま た、国際機関も官僚主義や外交上の理由から、後ろ手に 縛られた状態での活動になってしまっている。要するに、 現在の取り組みは、私たちが直面している脅威の大きさに 見合ったレベルに達していないのだ。

5 月 26 日号には、これらの問題点を深く掘り下げた記 事が掲載された。ウェブサイト (http://www.nature.com/ nature/focus/avianflu/index.html) でも、この問題に関し て Nature とその関連誌に揭載された記事を集めて、無料 で公開している。また、Nature は次の 2 組織とも連携して いる。論文誌 Foreign Affairs は次号 (6月下旬発行) で、 鳥インフルエンザやその他の世界的流行病の政策面に関 する調査結果を掲載する。さらに、この両誌が協賛して、 英国王立研究所世界科学会議が高いレベルの国際会議を 主催する。この会議は、全米科学財団の前長官 Rita Colwell が議長をつとめ、科学と政策の橋渡しをすること を目的としている。

でも何よりも、このインフルエンザに対するキャンペー ンについては、とりわけトップレベルの政治的監督を強化 する必要がある。もはや外交上のかけ引きや問題の否認 をしている場合ではない。人々の意識を高め、行動する 時なのである。 